\title{
Studies on Diaporthe eres as a New Pathogen of Peach Trees in Greece
}

Thomas Thomidis, Pomology Institute Naoussa (NAGREF), R. S. Naoussas 38, 59200, Imathia Greece; and
Themis J. Michailides, Department of Plant Pathology, University of California, Davis, Kearney Agriculture Center, Parlier 93648

\begin{abstract}
Thomidis, T., and Michailides, T. J. 2009. Studies on Diaporthe eres as a new pathogen of peach trees in Greece. Plant Dis. 93:1293-1297.

Phomopsis sp., the imperfect stage of the genus Diaporthe, is an increasingly common fungal pathogen of peach (Prunus persica). This study is the first report of the occurrence of a shoot blight and canker disease of peach in Greece caused by the fungus Diaporthe eres. The pathogen caused distinct cankers with abundant gumming on shoots of peach and nectarine trees. The rate of development of D. eres in vitro was reduced as temperatures increased from 25 to $30^{\circ} \mathrm{C}$ or decreased from 25 to $15^{\circ} \mathrm{C}$, and was totally inhibited at 35 and $10^{\circ} \mathrm{C}$. Storage at $10^{\circ} \mathrm{C}$ of peach fruit inoculated with $D$. eres controlled the development of fruit rot. Pathogenicity tests showed that 27 peach and nectarine cultivars grown in Imathia Prefecture, Greece, were equally susceptible to $D$. eres. The fungicides thiophanate methyl, carbendazim, tebuconazole, iprodione, and the mixture of cyprodinil:fludioxonil were evaluated against the development of $D$. eres and the disease symptoms. Thiophanate methyl, carbendazim, and tebuconazole significantly inhibited the growth of $D$. eres whereas iprodione and the mixture of cyprodinil:fludioxonil were less effective in inhibiting mycelial growth and disease symptoms. The sensitivity of 24 isolates of $D$. eres to carbendazim, thiophanate methyl, and tebuconazole was also tested. The results showed that most of the isolates used were sensitive to these fungicides, with some isolates showing a level of insensitivity. In general, the disease caused by $D$. eres could be a threat for peach cultivation in Greece and its management should be investigated in the field.
\end{abstract}

Peach (Prunus persica (L.) Batsch) is one of the most important crops of fruit trees worldwide. Specifically, peach production is a major industry in Greece, where the canned peach industry is rated as the second in size worldwide following that of the United States. The majority of acreage of peach for canning is located in Imathia county in northeastern Greece. This valley where peach is grown is about $100 \mathrm{~km}$ north of the sea and frequently is influenced by humid and hot days during the summer. A shoot blight has become an increasing problem in the peach production regions of the world, with serious economic consequences (11). Similarly, a severe decline of peach characterized by multiple blighted shoots per tree has occurred in northern Greece in recent years. Fungi of the genus Monilinia and, in some cases, Fusicoccum-like pathogens are believed to be primarily responsible for the occurrence of shoot blights in peach trees. Although the pathogen genus Phomopsis, the imperfect stage of the genus $\mathrm{Di}$ aporthe, has been reported as a cause for shoot blights of peach trees in many coun-

Corresponding author: T. Thomidis

E-mail: thomi-1@otenet.gr

Accepted for publication 20 July 2009.

doi:10.1094/PDIS-93-12-1293

(C) 2009 The American Phytopathological Society tries $(6,10,12,23,24)$, there are no reports of this disease in Greece.

Thus far, chemical control is the most effective method to manage diseases in fruit trees. Knowledge of the optimum temperatures for the development of $\mathrm{Di}$ aporthe spp. is essential to determine the best method and timing to apply fungicides against this pathogen in the field. Lalancette and Robison (13) reported that seven to eight fungicide sprays during leaf abscission in autumn reduced the incidence of constriction canker caused by Phomopsis amygdali in peach trees by 45 to $63 \%$. In contrast, four to five sprays from budbreak through bloom in spring provided only 10 to $28 \%$ control of the disease.

In Greece, the fungicides thiophanatemethyl, carbendazim, tebuconazole, and, recently, a mixture of cyprodinil and fludioxonil (Switch) are widely and repeatedly used for controlling shoot blights and fruit rots of peach but there is no research related to the tebuconazole-, thiophanatemethyl-, and carbendazim-resistant populations of the pathogen causing constriction canker of peach in Greece. Previous studies conducted in other parts of the world showed resistance to the benzimidazoles in field isolates of other Phomopsis spp. $(3,21)$.

The use of resistant tree cultivars is also important in controlling diseases because this is an environmental friendly method and growers do not expend funds for extraneous control measures such as fungi- cides. Cultivar resistance can be a useful complementary control measure even where fungicides must be used. Differences in the susceptibility of peach and nectarine cultivars on diseases caused by $P$. amygdale have been reported $(9,14,25)$.

The objectives of this study were to (i) investigate the effect of temperatures on development of Diaporthe eres, the pathogen causing shoot blight of peach in Greece (identified in this report); (ii) evaluate the susceptibility of 27 peach and nectarine cultivars to $D$. eres; (iii) evaluate the effectiveness of carbendazim, thiophanate methyl, tebuconazole, iprodione, and cyprodinil:fludioxonil fungicides against $D$. eres; and (iv) examine the sensitivity of $24 \mathrm{D}$. eres isolates in vitro to carbendazim, thiophanate methyl, and tebuconazole (these three fungicides are the most commonly used in peach production in Imathia, Greece, whereas iprodione is not widely used and the mixture cyprodinil:fludioxonil has been only recently registered in Greece).

\section{MATERIALS AND METHODS}

Isolation and identification of $D$. eres. In July and through the summer of 2005 and 2006, shoots of the cling peach $\mathrm{cv}$. Andross were wilted and blighted in commercial orchards in the County of Imathia in northern Greece. The affected shoots had distinct cankers with abundant gumming. Repeated isolations from the lower margins of the cankers were made by placing tissues of about 3 by 3 by $3 \mathrm{~mm}$ on acidified $(2.5 \mathrm{ml}$ of $85 \%$ lactic acid per liter of nutrient medium to create $\mathrm{pH}=3.5$ after autoclaving) potato dextrose agar (PDA). The dishes were incubated at $23^{\circ} \mathrm{C}$ for 5 to 7 days. Identification of the fungus was based on morphological characteristics and sporulation of three single-spore isolates (8). In addition, the fungal species was identified based on internal transcribed spacer (ITS) forward (V9G: TTA AGTCCCTGCCCTTTGTA) (4) and reverse (LS266: 5' GCATTCCCAAACAAC TCGACTC 3') (17) and translation elongation factor (EF) forward (EF1-728F: CATCGAGAAGTTCGAGAAGG) (2) and reverse (EF-2: GGA(G/A)GTACCAGT (G/C)ATCATGTT) (19) sequences by CBS Fungal Biodiversity Centre, Identification Service (Utrecht, The Netherlands).

Koch's postulates were completed in the laboratory by using the method described by Matheron and Matejka (18). Briefly, 10 segments of 1-year-old shoots of peach 
were similarly wounded and inoculated with an agar disk (from the margin of a 4 day culture) bearing mycelium of the fungus. Segments inoculated with an agar disk without fungal mycelium were used as control. All inoculated and control shoot segments were incubated at $25^{\circ} \mathrm{C}$ in moist chambers for 7 days, after which the resulting necrosis was recorded. The fungus was reisolated from the inoculated shoots that developed symptoms similar to those observed on shoots collected from orchards.

Effect of temperatures on development of pathogen. In a first experiment, an agar disk, $6 \mathrm{~mm}$ in diameter, taken from an active colony of $D$. eres, which originated from a blighted shoot of cv. Andross, was placed in the center of each of five replicated dishes (9 $\mathrm{cm}$ in diameter) containing PDA. Three single-spore isolates were used. The dishes were then incubated in a growth chamber at 2 to $4,10,15,20$, 25,30 , and $35^{\circ} \mathrm{C}$ for 4 days and the diameter of the resulting colony was recorded.

In a second experiment, mature fruit of the peach $\mathrm{cv}$. Andross were disinfested by dipping in $10 \%$ (vol/vol) household bleach (4.86\% sodium hypochlorite) for $15 \mathrm{~min}$ and allowed to dry in a transfer hood for $30 \mathrm{~min}$. Each fruit was wounded by removing epidermal tissues $(10 \mathrm{~mm}$ in diameter) using a razor and inoculated by placing a 6-mm mycelial disk of the fun-

Table 1. Effectiveness of fungicides against Diaporthe eres isolated from blighted peach on fungicide-amended potato dextrose agar medium

\begin{tabular}{|c|c|}
\hline Fungicides, rates & $\begin{array}{l}\text { Mycelial growth } \\
(\mathbf{m m})^{\mathrm{y}}\end{array}$ \\
\hline Control & $44.97 \mathrm{f}$ \\
\hline \multicolumn{2}{|l|}{ Tebuconazole } \\
\hline $0.40 \mathrm{ml} /$ liter & $0.00 \mathrm{a}$ \\
\hline $0.33 \mathrm{ml} /$ liter $^{\mathrm{z}}$ & $0.00 \mathrm{a}$ \\
\hline $0.26 \mathrm{ml} / \mathrm{liter}$ & $0.00 \mathrm{a}$ \\
\hline $0.20 \mathrm{ml} /$ liter & $0.00 \mathrm{a}$ \\
\hline \multicolumn{2}{|l|}{ Carbendazim } \\
\hline $1 \mathrm{~g} /$ liter & $0.00 \mathrm{a}$ \\
\hline $0.75 \mathrm{~g} /$ liter $^{2}$ & $0.00 \mathrm{a}$ \\
\hline $0.50 \mathrm{~g} /$ liter & $0.00 \mathrm{a}$ \\
\hline $0.30 \mathrm{~g} /$ liter & $0.00 \mathrm{a}$ \\
\hline \multicolumn{2}{|c|}{ Thiophanate methyl } \\
\hline $1.0 \mathrm{~g} /$ liter & $0.00 \mathrm{a}$ \\
\hline $0.70 \mathrm{~g} /$ liter $^{2}$ & $0.00 \mathrm{a}$ \\
\hline $0.50 \mathrm{~g} /$ liter & $0.00 \mathrm{a}$ \\
\hline $0.30 \mathrm{~g} /$ liter & $0.00 \mathrm{a}$ \\
\hline \multicolumn{2}{|c|}{ Cyprodinil:fludioxonil } \\
\hline $1.0 \mathrm{~g} / \mathrm{liter}$ & $0.00 \mathrm{a}$ \\
\hline $0.80 \mathrm{~g} /$ liter $^{2}$ & $3.70 \mathrm{bc}$ \\
\hline $0.50 \mathrm{~g} /$ liter & $5.66 \mathrm{~cd}$ \\
\hline $0.30 \mathrm{~g} /$ liter & $6.55 \mathrm{~cd}$ \\
\hline \multicolumn{2}{|l|}{ Iprodione } \\
\hline $1.33 \mathrm{ml} /$ liter & $1.48 \mathrm{ab}$ \\
\hline $1.0 \mathrm{ml} /$ liter $^{\mathrm{z}}$ & $5.88 \mathrm{~cd}$ \\
\hline $0.66 \mathrm{ml} /$ liter & $6.91 \mathrm{~cd}$ \\
\hline $0.47 \mathrm{ml} /$ liter & $9.07 \mathrm{~d}$ \\
\hline
\end{tabular}

${ }^{y}$ Values are the means of two experiments. Values followed by the same letters are not significantly different according to Tukey's highly significant difference at $P<0.05$.

${ }^{\mathrm{z}}$ Label-recommended rates as given by the manufacturer. gus taken from the margin of a 6-day-old culture in each wound site. In all, 150 inoculated fruit for each temperature (50 fruit for each single-spore isolate used) were placed in growth chambers at 2 to 4 , $10,15,20$, and $25^{\circ} \mathrm{C}$ for 6 days. The diameter of any rotted area was recorded after 7 days.

Pathogenicity and virulence of $D$. eres to 27 peach and nectarine cultivars. All the peach cultivars (Sunclo, Spring Crest, Andross, E. M. Crest, M. Bianca, June Gold, Spring Belle, Loadel, A37, Everts, E45, RedHaven, Sun Crest, Fortuna, H. D. Hale, Catherina, and Fayette) and nectarine cultivars (Fire Bright, Venus, Fantasia, Taste Free, Cal2000, Adriana, Red Gold, Rita Star, IB42, and May Grand) were established in the experimental field of the Pomology Institute (N.AG.RE.F.), Naoussa. Two D. eres isolates (originated from blighted shoots) were used to inoculate annual shoots (about $1 \mathrm{~cm}$ in diameter) in May 2006 and 2007. In all, 20 shoots were randomly selected from each cultivar and 10 for each isolate were used. The inoculum, which consisted of a 4-mm-diameter mycelial plug from a 4-day-old culture, was inserted in the middle of each shoot under the bark. The wound was covered with petroleum jelly and wrapped with adhesive tape to prevent desiccation. The results were collected 21 days after inoculation by recording the length of the resulting necrosis.

Effectiveness of fungicides against $\boldsymbol{D}$. eres. The effect of the fungicides carbendazim (PILAZIN 60WP; Hellafarm A.E.), thiophanate methyl (Thiophanate methyl 70WP; Inagro E.P.E.), tebuconazole (Folicur 25WG; Bayer), iprodione (Rovral 50WP; BASF), and the mixture cyprodinil: fludioxonil (Switch 25/37.5 WP; Syngenta) on mycelial growth of two isolates of $D$. eres was determined by growing fungi on PDA supplemented with each of the fungicides tested. Stock suspensions of fungicides were prepared by mixing the fungicide in sterile distilled water at concentrations presented in Table 1 and adding the appropriate amounts from the stock solution to PDA after autoclaving. An agar

Table 2. Effect of fungicides on development on excised peach shoots of Diaporthe eres isolated from blighted shoots of peach grown in Greece

\begin{tabular}{lcc}
\hline Fungicides & $\begin{array}{c}\text { Rate } \\
(\mathbf{p e r} \\
\text { liter })^{\mathbf{y}}\end{array}$ & $\begin{array}{c}\text { Length of } \\
\text { necrosis } \\
(\mathbf{m m})^{\mathbf{z}}\end{array}$ \\
\hline Thiophanate methyl & $0.70 \mathrm{~g}$ & $3.79 \mathrm{a}$ \\
Carbendazim & $0.75 \mathrm{~g}$ & $3.00 \mathrm{a}$ \\
Tebuconazole & $0.33 \mathrm{ml}$ & $11.69 \mathrm{~b}$ \\
Cyprodinil:fludioxonil & $0.80 \mathrm{~g}$ & $12.94 \mathrm{bc}$ \\
Iprodione & $1.0 \mathrm{ml}$ & $14.49 \mathrm{bc}$ \\
Control & $\ldots$ & $16.27 \mathrm{c}$ \\
\hline
\end{tabular}

y Doses recommended by producer.

${ }^{\mathrm{z}}$ Values are the means of two experiments. Values followed by the same letters are not significantly different according to Tukey's highly significant difference at $P<0.05$. plug (6 $\mathrm{mm}$ in diameter), taken from the margin of a 5-day actively growing colony of $D$. eres, was placed in the center of the agar in the dishes and the dishes incubated at $25^{\circ} \mathrm{C}$. Colony diameter measurements of mycelial growth were taken 4 days after initial transfer. Growth on agar not amended with fungicide was used to determine the degree of mycelial inhibition. Ten replicated dishes were used for each treatment.

In a second experiment, 1-year-old dormant shoots, $50 \mathrm{~cm}$ in length, were collected from 3-year-old KID I peach rootstocks and segments of $10 \mathrm{~cm}$ in length and $2 \mathrm{~cm}$ in diameter cut from the central part of each shoot. Trees did not show any symptoms of disease or signs of injury at this time. The segments were disinfested by dipping in a $10 \%$ domestic bleach $(4.86 \%$ sodium hypochloride) solution for $10 \mathrm{~min}$, washed with sterile-distilled water, and dried at room temperature on top of a laboratory bench over sterile paper towels. Each shoot was wounded with a sharp knife by removing $6 \mathrm{~mm}$ of bark from the central part. Segments were soaked in a fungicide suspension for $1 \mathrm{~min}$ and then dried by placing them on soft paper towels. Suspensions were prepared by mixing a fungicide in sterile distilled water at the labelrecommended concentration of active ingredients (Table 2$)$. Inoculations were made by inserting an agar plug $(6 \mathrm{~mm}$ in diameter) bearing mycelium of $D$. eres directly onto the cambium. Wounds were covered with adhesive tape to prevent desiccation and segments were incubated at $25^{\circ} \mathrm{C}$ for 10 days. There were 20 segments for each fungicide concentration and the experiment was repeated. The data were obtained by measuring the length of developed cankers.

In a third experiment, fruit (cv. Sun Cloud) were collected at harvest date and immediately transferred to the laboratory. They were disinfested by dipping in a $10 \%$ domestic bleach $(4.86 \%$ sodium hypochloride) solution for $10 \mathrm{~min}$, washed with sterile-distilled water, and dried at room temperatures on top of clean paper towels on a laboratory bench. Each fruit was wounded by removing a piece of skin, $3 \mathrm{~mm}$ in diameter, with a flamed needle and dipping it in a solution containing one of the test fungicides at the required concentration (label recommended rate; see Table 3). After drying, fruit were inoculated by placing a 6-mm mycelial disk, taken from the margins of a 7-day culture, onto each wound. The inoculated fruit were incubated in a growth chamber at $25^{\circ} \mathrm{C}$ for 5 days. There were 30 fruit for each fungicide treatment. Thirty fruit inoculated with an agar plug without mycelium were used as control. Results were collected by recording the diameter of decay.

Testing of $D$. eres isolates for their sensitivity to three fungicides. The sensitivity of $24 \mathrm{D}$. eres single-spore isolates, originated from blighted shoots and de- 
cayed peach fruit, to the fungicides thiophanate methyl and tebuconazole (widely used as preharvest sprays against fruit rots in Greece) were determined by growing the fungi on PDA amended with the appropriate fungicide. Stock suspensions were prepared by mixing the fungicide in sterile distilled water at label rates (Table 4). The fungicide suspension was added to the PDA after autoclaving and cooling the medium to $45^{\circ} \mathrm{C}$. An agar plug, $6 \mathrm{~mm}$ in diameter, taken from the margin of an actively growing colony of each isolate was placed in the center of the fungicidecontaining agar dishes and incubated at $25^{\circ} \mathrm{C}$ for 4 days, when colony diameter measurements were taken. Growth on agar without fungicide (control) was recorded and used to determine the degree of inhibition of mycelial growth by each fungicide. Five dishes were used for each combination of isolate and fungicide.

Statistical analysis. All experiments were conducted twice. Analysis of variance was used to analyze data. For analysis of data from combined experiments, Bartlett's test was used to demonstrate homogeneity of variances. Treatment means were separated by Tukey's test $(P<0.05)$ (SPSS Work Package 15).

\section{RESULTS}

Isolation and identification of $D$. eres. D. eres was isolated from peach blighted shoots. Consistent colonies with white mycelia developed from the majority of the diseased woody tissues. Darkly pigmented pycnidia (flask-shaped) and 1celled ovoid to fusoid (curved or bent) conidia were produced over the surface of the cankered area, oozing as milky or yellowish mucilaginous drops. In addition, the pathogen was identified as D. eres based on the ITS and EF sequence (Fig. 1).

Effect of temperatures on development of pathogen. The optimum temperature for mycelial growth of $D$. eres on PDA was $25^{\circ} \mathrm{C}$, whereas mycelial growth was inhibited at 35 and $10^{\circ} \mathrm{C}$ (Table 5). The mycelial growth of $D$. eres was significantly less at 20 than at $25^{\circ} \mathrm{C}$ but significant higher than that at 30 and $15^{\circ} \mathrm{C}$.

Table 3. Effect of fungicides on development of Diaporthe eres on peach fruit inoculated with mycelial plugs of the fungus

\begin{tabular}{lcc}
\hline Fungicides & $\begin{array}{c}\text { Rate } \\
\text { (per } \\
\text { liter) }\end{array}$ & $\begin{array}{c}\text { Diameter } \\
\text { of necrotic }^{\text {area }}\end{array}$ \\
\hline Tebuconazole & $0.33 \mathrm{ml}$ & $1.87 \mathrm{a}$ \\
Thiophanate methyl & $0.75 \mathrm{~g}$ & $2.83 \mathrm{a}$ \\
Carbendazim & $0.70 \mathrm{~g}$ & $4.10 \mathrm{a}$ \\
Cyprodinil:fludioxonil & $0.80 \mathrm{~g}$ & $7.29 \mathrm{~b}$ \\
Iprodione & $1.0 \mathrm{ml}$ & $11.83 \mathrm{c}$ \\
Control & $\ldots$ & $20.10 \mathrm{~d}$ \\
\hline y Label-recommended rates. \\
z Values are the means of two experiments. \\
\multicolumn{2}{l}{ Values followed by the same letters are not } \\
\multicolumn{2}{l}{ significantly different according to Tukey's } \\
\multicolumn{2}{l}{ highly significant difference at $P<0.05}$.
\end{tabular}

Finally, the mycelial growth of this fungus at $30^{\circ} \mathrm{C}$ was significantly higher than at $15^{\circ} \mathrm{C}$ (Table 5).

In artificially inoculated fruit, the pathogen caused decay lesions at $25^{\circ} \mathrm{C}$ whereas no decay developed at $\leq 10^{\circ} \mathrm{C}$ (Table 6).

Pathogenicity and virulence of $D$. eres to 27 peach and nectarine cultivars. Pathogenicity tests showed that all peach and nectarine cultivars artificially inoculated with the fungus $D$. eres developed symptoms of necrosis around the inoculation site. The lengths of necrosis ranged from 2.19 to $4.16 \mathrm{~cm}$ but were not significantly different from each other, and no differences were found in the virulence of D. eres isolates used (data not shown).

Effectiveness of fungicides against $\boldsymbol{D}$. eres. The mycelial growth of $D$. eres was inhibited completely on PDA amended with thiophanate methyl, carbendazim, or tebuconazole at concentrations lower than the label dosage recommended by the manufacturer (Table 1). However, iprodione and the mixture of cyprodinil: fludioxonil inhibited the mycelial growth only at concentrations higher than the labelrecommended rate. Lower concentrations of these fungicides inhibited the mycelial growth to a lesser degree than the higher concentrations.

When excised shoots were used, the benzimidazoles thiophanate methyl and carbendazim were the most effective of all fungicides tested in reducing the length of necrosis (Table 2). Tebuconazole also significantly reduced the length of necrosis in comparison with the untreated excised shoots, but this reduction was less than that resulting from treatment with thiophanate methyl or carbendazim. In contrast, iprodione and the mixture cyprodinil:fludioxonil did not affect the length of necrosis.

When peach fruit were dipped in fungicides, thiophanate methyl, tebuconazole, and carbendazim were the most effective in reducing the size of decay lesions (Table 3). However, iprodione and the mixture cyprodinil:fludioxonil were moderately effective in reducing the size of decay lesions.

Testing of $D$. eres isolates for their sensitivity to three fungicides. The results showed that most of the isolates used were sensitive to the fungicides tested (Table 4). However, three isolates (PI-Ph(1), PI-Ph(3), and $\mathrm{PI}-\mathrm{Ph}(8))$ of $D$. eres showed a level of insensitivity to both carbendazim and thiophanate methyl, whereas the isolate PI$\mathrm{Ph}(5)$ showed insensitivity only to thiophanate methyl. In addition, some level of insensitivity to both thiophanate methyl and tebuconazole was exhibited by isolate PI$\mathrm{Ph}(6)$, whereas isolate $\mathrm{PI}-\mathrm{Ph}(16)$ presented some level of insensitivity to all three tested fungicides.

\section{DISCUSSION}

Although $D$. eres has been previously reported as causal agent of shoot blights in other plant species, such as Acer pseudoplatanus and Juglans cinerea $(1,20)$, to our knowledge, this is the first report of the occurrence of this pathogen on peach in Greece, causing cankers that lead to shoot blight. However, P. amygdali, which may be the imperfect stage of a Diaporthe sp.,

Table 4. Effect of fungicides on mycelial growth $(\mathrm{mm})$ of 24 Diaporthe eres isolates collected from blighted shoots of peach in Imathia, Greece ${ }^{z}$

\begin{tabular}{|c|c|c|c|c|}
\hline Isolate & Control & Carbendazim & Thiophanate-methyl & Tebuconazole \\
\hline PI-Ph(1) & $37.4 \mathrm{a}$ & $38.3 \mathrm{a}$ & $37.6 \mathrm{a}$ & $0.0 \mathrm{~b}$ \\
\hline PI-Ph(2) & $46.1 \mathrm{a}$ & $0.0 \mathrm{~b}$ & $0.0 \mathrm{~b}$ & $0.0 \mathrm{~b}$ \\
\hline PI-Ph(3) & $48.8 \mathrm{a}$ & $16.9 \mathrm{~b}$ & $19.8 \mathrm{~b}$ & $0.0 \mathrm{c}$ \\
\hline $\mathrm{PI}-\mathrm{Ph}(4)$ & $46.2 \mathrm{a}$ & $0.0 \mathrm{~b}$ & $0.0 \mathrm{~b}$ & $0.0 \mathrm{~b}$ \\
\hline $\mathrm{PI}-\mathrm{Ph}(5)$ & $61.4 \mathrm{a}$ & $0.0 \mathrm{c}$ & $14.3 \mathrm{~b}$ & $0.0 \mathrm{c}$ \\
\hline PI-Ph(6) & $62.4 \mathrm{a}$ & $0.0 \mathrm{c}$ & $9.1 \mathrm{~b}$ & $12.0 \mathrm{~b}$ \\
\hline PI-Ph(7) & $60.0 \mathrm{a}$ & $0.0 \mathrm{c}$ & $0.0 \mathrm{c}$ & $12.3 \mathrm{~b}$ \\
\hline PI-Ph(8) & $25.8 \mathrm{a}$ & $4.5 \mathrm{bc}$ & $6.8 \mathrm{~b}$ & $0.0 \mathrm{c}$ \\
\hline PI-Ph(10) & $70.7 \mathrm{a}$ & $0.0 \mathrm{~b}$ & $0.0 \mathrm{~b}$ & $0.0 \mathrm{~b}$ \\
\hline $\mathrm{PI}-\mathrm{Ph}(11)$ & $40.3 \mathrm{a}$ & $0.0 \mathrm{~b}$ & $0.0 \mathrm{~b}$ & $00.0 \mathrm{~b}$ \\
\hline $\mathrm{PI}-\mathrm{Ph}(12)$ & $60.2 \mathrm{a}$ & $0.0 \mathrm{~b}$ & $0.0 \mathrm{~b}$ & $0.0 \mathrm{~b}$ \\
\hline $\mathrm{PI}-\mathrm{Ph}(13)$ & $60.1 \mathrm{a}$ & $0.0 \mathrm{~b}$ & $0.0 \mathrm{~b}$ & $0.0 \mathrm{~b}$ \\
\hline $\mathrm{PI}-\mathrm{Ph}(14)$ & $50.8 \mathrm{a}$ & $0.0 \mathrm{~b}$ & $0.0 \mathrm{~b}$ & $0.0 \mathrm{~b}$ \\
\hline PI-Ph(15) & $40.7 \mathrm{a}$ & $0.0 \mathrm{~b}$ & $0.0 \mathrm{~b}$ & $0.0 \mathrm{~b}$ \\
\hline $\mathrm{PI}-\mathrm{Ph}(16)$ & $60.2 \mathrm{a}$ & $8.8 \mathrm{~b}$ & $8.0 \mathrm{~b}$ & $11.1 \mathrm{~b}$ \\
\hline PI-Ph(17) & $60.5 \mathrm{a}$ & $0.0 \mathrm{~b}$ & $0.0 \mathrm{~b}$ & $0.0 \mathrm{~b}$ \\
\hline PI-Ph(18) & $60.1 \mathrm{a}$ & $0.0 \mathrm{~b}$ & $0.0 \mathrm{~b}$ & $0.0 \mathrm{~b}$ \\
\hline $\mathrm{PI}-\mathrm{Ph}(19)$ & $60.9 \mathrm{a}$ & $0.0 \mathrm{~b}$ & $0.0 \mathrm{~b}$ & $0.0 \mathrm{~b}$ \\
\hline $\mathrm{PI}-\mathrm{Ph}(20)$ & $70.6 \mathrm{a}$ & $0.0 \mathrm{~b}$ & $0.0 \mathrm{~b}$ & $0.0 \mathrm{~b}$ \\
\hline $\mathrm{PI}-\mathrm{Ph}(21)$ & $50.8 \mathrm{a}$ & $0.0 \mathrm{~b}$ & $0.0 \mathrm{~b}$ & $0.0 \mathrm{~b}$ \\
\hline $\mathrm{PI}-\mathrm{Ph}(22)$ & $71.0 \mathrm{a}$ & $0.0 \mathrm{~b}$ & $0.0 \mathrm{~b}$ & $0.0 \mathrm{~b}$ \\
\hline PI-Ph(23) & $60.8 \mathrm{a}$ & $0.0 \mathrm{~b}$ & $0.0 \mathrm{~b}$ & $0.0 \mathrm{~b}$ \\
\hline $\mathrm{PI}-\mathrm{Ph}(24)$ & $60.6 \mathrm{a}$ & $0.0 \mathrm{~b}$ & $0.0 \mathrm{~b}$ & $0.0 \mathrm{~b}$ \\
\hline $\mathrm{PI}-\mathrm{Ph}(25)$ & $70.5 \mathrm{a}$ & $0.0 \mathrm{~b}$ & $0.0 \mathrm{~b}$ & $0.0 \mathrm{~b}$ \\
\hline
\end{tabular}

${ }^{\mathrm{z}}$ Fungicide doses recommended by the manufacturer (PILAZIN 60WP $=0.7 \mathrm{~g} /$ liter, Thiophanate methyl 70WP $=0.7 \mathrm{~g} / \mathrm{liter}$, and Folicur $25 \mathrm{WG}=0.33 \mathrm{ml} / \mathrm{liter}$ ). Values are the means of two experiments. Values in the same row followed by the same letters are not significantly different according to Tukey's highly significant difference at $P<0.05$. 
causes shoot blight and constriction canker of peach in Georgia $(6,23,24)$.

It is essential to know the optimum, maximum, and minimum temperatures for the development of $D$. eres before a decision for the method and time of controlling the disease is made. Representative isolates of $D$. eres from peach grew between 15 and $30^{\circ} \mathrm{C}$ and showed an optimum growth at $25^{\circ} \mathrm{C}$. However, Jiang et al. (7) found that the optimum temperature for mycelial development of the fungus $P$. brevistylospora (isolated from fruit of rockmelon with symptoms of rot) on PDA was between 22.5 and $30^{\circ} \mathrm{C}$.

Cold storage of fruit immediately after harvest may be a method to control the postharvest occurrence of Phomopsis fruit rot (5). The results of this study showed that artificially inoculated peach fruit with $D$. eres did not develop any symptoms of rot when they were stored at $10^{\circ} \mathrm{C}$ or lower temperatures. According to Eguchi and Hara (5), a core rot of pear caused by Phomopsis spp. developed in storage at $15^{\circ} \mathrm{C}$ or higher, whereas no rot developed when pear fruit were stored at $12.5^{\circ} \mathrm{C}$ or lower.

\section{$\underline{\text { ITS-Sequence }^{\mathrm{a}}}$}

СTGCACTACCGATTGATGGTTCAGTGAGGCTTTCGGACTGGCCCAGGGAGGTCGGCAACGACCACCCAG

GGCCGGAAAGTTATCCAAACTCGATCATTTAGAGGAAGTAAAAGTCGTAACAAGGTCTCCGTTGGTGAA

CCAGCGGAGGGATCATTGCTGGAACGCGCCCCAGGCGCACCCAGAAACCCTTTGTGAACTTATACCTTA

СTGTTGCCTCGGCGCTAGCTGGTCCTTCGGGGCCCCTCACCCTCGGGTGTTGAGACAGCCCGCCGGCGG

CCAACCCAACTCTTGTTTTTACACTGAAACTCTGAGAATAAAACATAAATGAATCAAAACTTTCAACAA

CGGATCTCTTGGTTCTGGCATCGATGAAGAACGCAGCGAAATGCGATAAGTAATGTGAATTGCAGAATT

CAGTGAATCATCGAATCTTTGAACGCACATTGCGCCCTCTGGTATTCCGGAGGGCATGCCTGTTCGAGC

GTCATTTCAACCCTCAAGCCTGGCTTGGTGATGGGGCACTGCTTTTACCCAAGAGCAGGCCCTGAAATT

CAGTGGCGAGCTCGCCAGGACCCCGAGCGCAGTAGTTAAACCCTCGCTCTGGAAGGCCCTGGCGGTGCC

CTGCCGTTAAACCCCCAACTTCTGAAAATTTGACCTCGGATCAGGTAGGAATACCCGCTGAACTTAAGC

ATATCAATAAGCGGAGGAAAAGAAACCAACAGGGATTGCCCTAGTAACGGCGAGTGAAGCGGCAACAGC

TCAAATTTGAAATCTGGCCTCGGCCCGAGTTGTAATTTGCAGAGGATGCTTCTGGCGCGGTGCCTTCCG

AGTTCCCTGGAACGGGACGCCACAGAGGGTGAGAGCCCCGTATGGTCGGACACCAAGCCTGTGAGT

\section{$\underline{E F-S e q u e n c e}^{\mathrm{a}}$}

GAGGAAGGTTAGTAAATATCACAGTCACGGAACATGCTACCTGGCCCTCCATACTGCACCTCAATCATC

AGCCCGCAGCTGCTCGCGCGGCCTCGCCATGTCGGGGGGGCGCATTTTCACCCCTCGCTTTGGATTTTC

CATTTTCAGTGCGAGTGCGGGGTGCGCTTATCAGGGGGCGGGCTTATCTCCTACAACCAAAACCCCTGT

TACATCACTCACTCAATCCTTGTCACCACCACCCAATACGCTCACCATCAACCCCATCGCCTCTTTCAA

TACAACTCGTGAAACGCGTCGAATATTATGCTGACCCTCTATCTACACAGCCGCCGAGCTTGGCAAGGG

TTCCTTCAAGTACGCCTGGGTTCTGGACAAGCTGAAGGCCGAGCGTGAGCGTGGTATCACTATCGACAT

TGCCCTCTGGAAGTTCGAGACTCCCAAGTACTATGTCACCGTCATTGGTATGTTTCAATCCTTCATTGA

ACGTCCTCCGAGCTGCCGGTCCATACCAGAGGACCGAGTCGCTGTGGATGTTTCCAATCATGATAACAC

TCGCTGACACGGTTACCTTCCAGACGCTCCCGGTCACCGTGACTTCATCAAGAACATG

${ }^{\text {a }}$ Provided by CBS Identification Centre (The Netherlands).

Fig. 1. Internal transcribed spacer (ITS) and translation elongation factor (EF) sequences (provided by CBS Identification Centre, The Netherlands) of $D i$ aporthe eres isolates collected from blighted shoots of peach grown in Imathia Prefecture, Greece. 
All peach and nectarine cultivars tested in this study were equally susceptible to infection by $D$. eres, although levels of susceptibility could not be compared with a resistant cultivar because one has not been yet identified in Greece. Voronin and Kartausova (25) reported different degrees of resistance to shoot blight in peach cultivars in the Crimea, Russia. According to Latham et al. (14), after an epidemic of shoot dieback caused by $P$. persicae occurred in $75 \%$ of peach orchards in central Alabama, United States, the percentage of infection varied with cultivar. It is possible that, if an epidemic of the shoot blight caused by $D$. eres on peach grown in Imathia, Greece, had occurred, differences in disease susceptibility among the many cultivars grown in this area could have been found. Lalancette (9) indicated that peach cv. Biscoe was susceptible to constriction canker caused by $P$. amygdali and attained high yield losses.

This study also showed that all three $D$. eres isolates were equally virulent when tested on peach shoots in field. Similarly, Uddin et al. (23) found that there was no significant difference in virulence among the five isolates of Phomopsis tested after artificial inoculation of peach shoots of $\mathrm{cv}$. Babygold-7.

In all experiments, the carbendazim, thiophanate methyl, and tebuconazole fungicides inhibited the development of $D$. eres, suggesting that these fungicides can be effective in controlling the disease. The effectiveness of thiophanate methyl against $P$. amygdali causing constriction canker of peach has been reported $(22,27)$. Further-

Table 5. Effect of temperatures on mycelial growth of Diaporthe eres isolates collected from blighted shoots of peach in Greece ${ }^{\mathrm{z}}$

\begin{tabular}{lc}
\hline Temperatures $\left({ }^{\circ} \mathbf{C}\right)$ & Mycelial growth $(\mathbf{m m})$ \\
\hline 10 & $0.00 \mathrm{a}$ \\
35 & $0.00 \mathrm{a}$ \\
15 & $9.21 \mathrm{~b}$ \\
30 & $33.53 \mathrm{c}$ \\
20 & $43.14 \mathrm{~d}$ \\
25 & $48.20 \mathrm{e}$ \\
\hline
\end{tabular}

${ }^{z}$ Values are the means of two experiments. Values followed by the same letters are not significantly different according to Tukey's highly significant difference at $P<0.05$.

Table 6. Effect of temperatures on the development of decay lesion of mature peach fruit caused by Diaporthe eres isolated from blighted shoots of peach in Greece ${ }^{\mathrm{z}}$

\begin{tabular}{lc}
\hline Temperatures $\left({ }^{\circ} \mathbf{C}\right)$ & Diameter of lesion $(\mathbf{m m})$ \\
\hline 25 & $45.34 \mathrm{a}$ \\
20 & $37.33 \mathrm{~b}$ \\
15 & $18.22 \mathrm{c}$ \\
10 & $0.00 \mathrm{~d}$ \\
$2-4$ & $0.00 \mathrm{~d}$ \\
\hline
\end{tabular}

${ }^{\mathrm{z}}$ Values are the means of two experiments. Values followed by the same letters are not significantly different according to Tukey's highly significant difference $(P<0.05)$. more, the fungicides tebuconazole and carbendazim reduced the incidence of Phomopsis blight of brinjal trees (16). Similarly, Long et al. (15) reported that tebuconazole was effective against $P . l i$ monii of Limonium cv. Chorus Magenta. Although the fungicide iprodione and the mixture cyprodinil:fludioxonil reduced the development of $D$. eres in our study, these fungicides were less effective than carbendazim, thiophanate methyl, and tebuconazole in reducing all the development of $D$. eres, the size of the cankers in excised shoots, and decay lesion of the fruit. Washington et al. (26) evaluated a number of fungicides against $P$. castanea of chestnuts and found that iprodione was less effective in controlling the fungus than benomyl, imazalil, prochloraz, and propiconazole.

In this study, isolates of $D$. eres insensitive to benzimidazole fungicides (thiophanate methyl and carbendazim) and tebuconazole were found (Table 4). Populations of $P$. asparagi resistant to benzimidazoles have been previously found by Chen and Ye (3). Spalding (21) reported resistant isolates of $P$. citri on the fungicide benomyl. To our knowledge, this is the first report of tebuconazole-resistant isolates of $D$. eres. Alternative methods to manage tebuconazole- and benzimidazoleresistant isolates of $D$. eres causing shoot blight of peach should be investigated.

In conclusion, although restriction canker and other shoot blights of peach were attributed to $P$. amygdali and other Phomopsis spp., to our knowledge this is the first report of $D$. eres causing shoot blight of peach worldwide.

\section{LITERATURE CITED}

1. Anagnostakis, S. L. 2007. Diaporthe eres (Phomopsis oblonga) as a pathogen of butternut (Juglans cinerea) in Connecticut. Plant Dis. 91:1198.

2. Carbone, I., and Kohn,. L. M. 1999. A method for designing primer sets for speciation studies in filamentous ascomycetes. Mycologia 91:553-556.

3. Chen, X. J., and Ye, Z. Y. 1999. Preliminary study on resistance of Phomopsis asparagi Sacc. to thiophanate-methyl. J. Nanjing Agric. Univ. 22:29-32.

4. De Hoog, G. S., and van den Ende, G. 1998. Molecular diagnostic of clinical strain of filamentous Basidiomycetes. Mycoses 41(56):183-189.

5. Eguchi, N., and Hara, H. 2005. Influence of preservation temperature on rot extent of fruit core rot of Japanese pear caused by Phomopsis spp. Annu. Rep. Kanto-Tosan Plant Prot. Soc. 52:51-52.

6. Farr, D. F., Castlebury, L. A., and PardoSchultheiss, R. A. 1999. Phomopsis amygdali causes peach shoot blight of cultivated peach trees in the southeastern United States. Mycologia 91:1008-1015.

7. Jiang, X. Q., Wang, W., Tang, J. H., and Guo, Y. R. 2007. Characteristics and biocontrol of Phomopsis rot on postharvest rockmelon. Acta Phytophylacica Sin. 34:129-135.

8. Kanematsu, S., Kobayashi, T., Kudo, A., and Ohtsu, Y. 1999. Conidial morphology, pathogenicity and culture characteristics of Phomopsis isolates from peach, Japanese pear and apple in Japan. Ann. Phytopathol. Soc.
Jpn. 65:264-273.

9. Lalancette, N. 1999. Fusicoccum canker of peach disease incidence and yield loss. Pa. Fruit News 79:44-45.

10. Lalancette, N., Foster, K. A., and Robison, D. M. 2003. Quantitative models for describing temperature and moisture effects on sporulation of Phomopsis amygdali on peach. Phytopathology 93:1165-1172.

11. Lalancette, N., and Polk, D. F. 2000. Estimating yield and economic loss from constriction canker of peach. Plant Dis. 84:941-946.

12. Lalancette, N., and Robison, D. M. 2001. Seasonal availability of inoculum for constriction canker of peach in New Jersey. Phytopathology 91:1109-1115.

13. Lalancette, N., and Robison, D. M. 2002. Effect of fungicides, application timing, and canker removal on incidence and severity of constriction canker of peach. Plant Dis. 86:721-728.

14. Latham, A. J., Morgan-Jones, G., and Campbell, H. L. 1992. Phomopsis dieback of peach shoots in Alabama. Plant Dis. 76:426.

15. Long, P. G., Funnell, K. A., Fountain, W. F., Bendall, M., and Morgan, E. R. 2001. Control of a stem canker caused by Phomopsis limonii on Limonium 'Chorus Magenta'. N. Z. J. Crop Hortic. Sci. 29:247-253.

16. Manna, B. K., Jash, S., Srikanta D., and Das, S.N. 2004. Effects of environmental factors on Phomopsis blight of brinjal and its management. Ann. Plant Prot. Sci. 12:229-231.

17. Masclaux, F., Gueho, E., Hood, G. S., and Christen, R. 1995. Phylogenetic relationship of human-pathogenic Cladosporium (Xylohypha) species inferred from partial LS rRNA sequences. J. Med. Vet. Mycol. 33:327-338.

18. Matheron, M. E., and Matejka, J. C. 1988. Phytophthora root and crown rot of apple trees in Arizona. Plant Dis. 72:481-484.

19. O'Donnell, K., Kistler, H. C., Cigelnik, E., and Ploetz, R. C. 1998. Multiple evolutionary origins of the fungus causing Panama disease of banana: concordant evidence from nuclear and mitochondrial gene genealogies. Proc. Natl. Acad. Sci. USA 95:2044-2049.

20. Quaroni, S., Sardi, P., and Locci, R. 1980 Apical blight in Acer pseudoplatanus associated with Diaporthe eres Nits. (Phomopsis acerina Pir. et Cart). Riv. Patol. Veg. 16:109.

21. Spalding, D. H. 1982. Resistance of mango pathogens to fungicides used to control postharvest diseases. Plant Dis. 66:1185-1186.

22. Tuset, J. J., Hinarejos, C., and Portilla, M. T. 1997. Incidence of Phomopsis amygdali, Botryosphaeria berengeriana and Valsa cincta diseases in almond under different control strategies. Bull. OEPP 27:449-454.

23. Uddin, W., Stevenson, K. L., and PardoSchultheiss, R. A. 1997. Pathogenicity of a species of Phomopsis causing a shoot blight on peach in Georgia and evaluation of possible infection courts. Plant Dis. 81:983-989.

24. Uddin, W., Stevenson, K. L., PardoSchultheiss, R. A., and Rehner, S. A. 1998. Pathogenic and molecular characterization of three Phomopsis isolates from peach, plum, and Asian pear. Plant Dis. 82:732-737.

25. Voronin, E. I., and Kartausova, V. A. 1990 Phomopsis blight of peach in the Crimea. Nauchno-Tekhnicheskii Byulleten' Vsesoyuznogo Ordena Lenina i Ordena Druzhby Narodov Nauchno-Issledovatel'skogo Instituta Rastenievodstva imeni N. I. Vavilova 205:52-53.

26. Washington, W. S., Hood, V., Goubran, F., Hepworth, G., and Stewart-Wade, S. 1998. Effect of fungicides applied as foliar sprays and trunk injections on nut rot of chestnuts caused by Phomopsis castanea in Victoria. Aust. J. Exp. Agric. 38:295-303.

27. Ye, Y., and Pu, B. 2004. Experiment of testing the capability of Tianranzhibao agent to control peach fruit rot disease. South China Fruits 33:62. 